\title{
PECULIARITIES OF ATTITUDES OF MEDICAL STUDENTS TO EUTHANASIA: THE PSYCHOLOGICAL ASPECT
}

\author{
Katolyk H. V.
}

\section{INTRODUCTION}

In different countries throughout the world there is a positive trend today to vest physicians with the right to "decide their patients" fate". Perhaps this trend has its own dynamic social patterns in the context of global processes. During social historical events, doctors, despite their professional mission to protect, prolong and improve the patient's quality of life (Code of Medical Ethics), would cross the red lines of social and "moral" permissibility and consider it a universal human boon to "assist" a sick person to meet his/her death faster, regarding it as "easy, painless death".

It should be noted that the essential duty of physicians and the task of medicine as a whole is to state the patient's condition at the moment when the heart muscle stops contracting, blood no longer flows to the brain, as a result of which brain activity ceases and the person is considered dead. The medical certification issued by a physician in this case acts as a necessary legal document, which formally initiates all the mourning rituals associated with the burial of a deceased person, and as a legal act, which legally makes children orphans, a man - a widower, and a woman - a widow, etc. (M. Levkut, J. Binnebesel, A. Vlasova, H. Katolyk ${ }^{2}$.

It is clear that society empowers physicians with very important functions, giving them the right to determine the time of death. Basically, these functions seem obvious and quite acceptable to us. Traditionally, in medicine, death is defined as a natural irrevocable cardiac and respiratory arrest; however, for

${ }^{1}$ Andrusiv S.V. Criminal Law of Ukraine: Special Part. Textbook; Ed. by P.S. Matyshevskyi et al. K. : Yurinkom Inter, 1999. 45 p.

Binnebesel J., Katolyk H. Perception of fear of death in the context of Thanatopedagogical Relational Replacement Therapy / H.V. Katolyk, J. Binnebesel // Psychology and personality. 2015. No. 2 (8), part 2. P. 208-222.

Primachenko V. F. The issue of euthanasia in the criminal law of Ukraine. Publishing House "Law and Security", 2002. P. 5-11.

${ }^{2}$ Palliative and hospice care: extra-medical multidimensional aspects / under the scientific editorship of J. Binnebesel, H. Katolyk. Lviv: Ukrainian Catholic University - Nowa Wies: Wydawnictwo Rolewski, 2018. 411 p.

Primachenko V. F. The issue of euthanasia in the criminal law of Ukraine. Publishing House "Law and Security", 2002. P. 5-11. 
several decades the topic of euthanasia has been gaining wide discourse in this context. This manipulation is described in scientific sources as "humane, easy death", though many scholars are inclined to think that it cannot be considered "positive", given the various ethical, medical, psychological and moral aspects of conducting it ${ }^{3}$.

However, it should be noted that supporters of euthanasia still find arguments in favour of accelerating the death of a patient "in need". This worldview is adapted in a considerable number of states, though it is legalized only in several countries, including the Netherlands, Belgium, Luxembourg, the states of Washington and Oregon in the USA ${ }^{4}$.

Despite the legal ban on euthanasia in Ukraine, several desperate attempts have been made at the beginning of the $21^{\text {st }}$ century aimed at changing this situation. When amending the Civil Code of Ukraine, euthanasia advocates decided to make their amendments to allow passive euthanasia. However, such an attempt was not supported, given sensible comments and warnings on the subjective factor in medical practice (professional errors) ${ }^{5}$.

The situation with severe patients in our country is disappointing. Doctors have low salaries, patients lack funds for medicines, there is inadequate care for patients by caregivers and family - these are not the only reasons for the existence of different worldview trends in society regarding euthanasia. Despite the positive trends in opening hospices and palliative wards in hospitals, the idea of "easy death" is passively promoted. Based on our research in 2018-2019 (H. Katolyk, M. Levkut), we observe a shift in thinking among future physicians in favour of euthanasia. The reason for this

\footnotetext{
${ }^{3}$ Binnebesel J., Katolyk H. Perception of fear of death in the context of Thanatopedagogical Relational Replacement Therapy / H.V. Katolyk, J. Binnebesel // Psychology and personality. 2015. No. 2 (8), part 2. P. 208-222.

Palliative and hospice care: extra-medical multidimensional aspects / under the scientific editorship of J. Binnebesel, H. Katolyk. Lviv: Ukrainian Catholic University - Nowa Wies: Wydawnictwo Rolewski, 2018. 411 p.

${ }^{4}$ Sekatskiy A.K. Escape and deception in a single combat with death / in the book: The Psychology of Dying and Death: Reader / Comp. by K.V. Selchenok. Minsk. : Harvest, 1998. P. 79-82.

Dowbiggin I., "A merciful end: The euthanasia movement in modern America", New York: Oxford University Press, Inc; 2003.

Phillips P., "Physician-assisted suicide, euthanasia and palliative sedation: attitudes and knowledge of medical students", GMS Journal for Medical Education, 2016. 42 p.

${ }^{5}$ Parakhnevich A.S., Portnova A.G. Particular nature of experiencing the fear of death in terms of the age-sex aspect. Publishing House "Genesis", 2006. P. 12-15.

Sekatskiy A.K. Escape and deception in a single combat with death / in the book: The Psychology of Dying and Death: Reader / Comp. by K.V. Selchenok. Minsk. : Harvest, 1998. P. 79-82.
} 
phenomenon is empathy for the suffering of the patient, whose quality of life is extremely low due to the slow pace of modernization of medical care and the low quality of medical support, etc. ${ }^{6}$ Therefore, based on the contemporary worldview and social contradictions, in particular in the medical field, concerning the urgent issues of euthanasia as a social value and phenomenon, and based on the purpose of our study, which consisted of a theoretical study and an empirical description of the attitude of modern medical students in Ukraine towards euthanasia, the study object was formulated, namely, the attitude to euthanasia as a psychological phenomenon, and the scope of research (subject) covers the peculiarities of the attitude of medical students to euthanasia.

According to the object and subject of the study, we have formulated the objectives and identified a range of scientific hypotheses which suggested that medical university students have:

1) invariance in perceptions and attitudes towards euthanasia;

2) differences in terminal and instrumental values;

3) a negative attitude to euthanasia, in the presence of high levels of empathy;

4) different projections of their own implicit and explicit experiences on the phenomenon of euthanasia. Implicit experience influences the formation of attitudes towards euthanasia through unconscious experienced situations that are in a latent state. With the help of external triggers, the existence of an attitude towards euthanasia manifests itself.

The methodology of the study consisted of the following methods: a questionnaire for identifying attitudes toward euthanasia, K. Leonhard S. Schmishek questionnaire for studying personality accentuations, A. Mehrabian and N. Epstein's Questionnaire Measure of Emotional Empathy, M. Rokich's technique of Value Orientations, as well as a projective symbol test that reflects the perception of euthanasia.

Theoretical and practical significance of the study was to theoretically summarize and statistically reflect the attitude of modern medical students to euthanasia, which could be an impetus for a change in existences regarding the problem of euthanasia in the medical environment.

${ }^{6}$ Sekatskiy A.K. Escape and deception in a single combat with death / in the book: The Psychology of Dying and Death: Reader / Comp. by K.V. Selchenok. Minsk. : Harvest, . P. 79$82 \mathrm{p}$.

Phillips P., "Physician-assisted suicide, euthanasia and palliative sedation: attitudes and knowledge of medical students", GMS Journal for Medical Education, 2016. 42 p.

O'donnell T.J., "Morals in medicine", The newman press, Westminster, Maryland, 1956. P. 190-193. 


\section{Historical aspect of the attitude towards euthanasia in a medical context: scientific rewind}

It is believed that the term "euthanasia" (from the Greek "eu" - well or good and "thanatos" - death) was first adopted by Francis Bacon (as noted by C. Campbell and E. Fey) to refer to an "easy death", although the first studies and mentions of this phenomenon are found in works by ancient Greek philosophers and physicians. In particular, the positive attitude towards euthanasia and its use by Hippocrates in the medical practice is mentioned in numerous modern studies. According to Francis Bacon, medicine should be humane, namely, that it should in any way alleviate the suffering of the patient, up to anaesthesia in the form of deprivation of his/her life ${ }^{7}$.

One of the most famous physicians of the $19^{\text {th }}$ century in Germany, C.W. Hufeland condemned doctors who were indifferent to dying patients and asked them not to leave the patients until their death in order to at least alleviate their suffering. Another German scientist, Johann Christian Reil, in his works on euthanasia emphasized that it was the duty of every doctor to facilitate the "leaving" of the patient ${ }^{8}$. After the $30 \mathrm{~s}$ of the $20^{\text {th }}$ century there was a state policy regarding euthanasia in Germany, where it was applied on a large scale and for specific purposes. So, for example, in 1939, A. Hitler signed a decree on the registration of disabled children. The same thing was done for people of different ages with mental retardation. That register was carried out with the purpose of registering persons "overburdening" the nation and subjecting them to euthanasia: the goal was to "strengthen the health" of the "Aryan race". There is evidence that 5000 children were artificially deprived of their lives. Let us note the objectification of some periods when euthanasia was used in modern history of mankind: the $18^{\text {th }}$, $19^{\text {th }}, 20^{\text {th }}$ centuries were filled with revolutions and wars when the procedure for accelerating the onset of death was in demand due to the mass suffering of the wounded and sick, while medical aid and medicines were sorely lacking. In the post-war period, after social communities of different countries analysed the crimes of the World War II, euthanasia was criticized and prohibited ${ }^{9}$.

\footnotetext{
${ }^{7}$ Campbell C, Fahy T. Suicide and schizophrenia. Psychiatry. 2005.

${ }^{8}$ Selchenok K.V. Analysis of the consumer's inner experiences / The Psychology of dying and death: Reader - Publishing house "Harvest", 1998. P. 3-11.

${ }^{9}$ Kyrylenko T.S., Myronchak K.V. Specific features of experiencing the fear of death in various life situations: cognitive, emotional and behavioural aspects. 2010. P. 82.

Parakhnevich A.S., Portnova A.G. Particular nature of experiencing the fear of death in terms of the age-sex aspect. Publishing House "Genesis", 2006. P. 12-15.

Study Guide: An Introduction to Bioethics. / Ed. by B.G. Yudin, P.D. Tishchenko. M. : Progress-Tradition, 1998. $190 \mathrm{p}$.
} 
However, over time, in England and the United States the question arose of allowing a dying person to ask a physician to help hasten his/her death. The role of the doctor in this case was primarily determined by the need to correctly diagnose an incurable disease, and also by the fact that the doctor had to have medications that would allow to stop the suffering of a person by depriving him/her of his/her life. Since then, the term "euthanasia" has become popular and has been steadily striding across the countries of Europe and America. In the 70s of the last century, a new postmodern culture was formed in the USA and European countries, whose representatives tried to find and substantiate moral standards regarding the phenomenon of life and death. First of all, it was about the "right to die" and "easy death"10.

The issues of the human right to die are still debated contentiously (J. Binnebesel, B. Antoszewska, S. Urbański, H. Katolyk, P. Krakowiak, D. Krzyżanowski, M. Levkut, A. Modlińska, A. Janowicz, and others). There are scientific studies that examined the issues of legalizing the 'mercy killing' of patients. Russian scientist A. F. Koni considered it possible to allow euthanasia in medical practice, however, only in the presence of clear conditions and rules, which might include the following:

1) the patient must be conscious when requesting or making a decision on euthanasia;

2) there is the possibility of alleviating his/her suffering using existing means;

3) it is necessary to prove the impossibility to save the patient's life, and doctors must take a unanimous decision on euthanasia ${ }^{11}$.

Ardelt M., "Effects of Religion and Purpose in Life on Elders' Subjective Well-Being and Attitudes toward Death". Journal of Religious Gerontology, 2002. P. 163-192.

${ }^{10}$ Ardelt M., "Effects of Religion and Purpose in Life on Elders' Subjective Well-Being and Attitudes toward Death". Journal of Religious Gerontology, 2002. P. 163-192.

Baergen R., "Ethics at the end of life", Idaho state university, 2001. P. 1-38, 42-46.

Dowbiggin I., "A merciful end: The euthanasia movement in modern America", New York: Oxford University Press, Inc; 2003.

Phillips P., "Physician-assisted suicide, euthanasia and palliative sedation: attitudes and knowledge of medical students", GMS Journal for Medical Education, 2016. 42 p.

Gandhi A.,"Desire for death in cancer patients - an Indian Study", Presented at the International Congress of the International Psycho OncologySociety, Copenhagen, 2004. P. 39-128.

O'donnell T.J., "Morals in medicine", The newman press, Westminster, Maryland, 1956. P. 190-193.

${ }^{11}$ Binnebesel J., Katolyk H. Perception of fear of death in the context of Thanatopedagogical Relational Replacement Therapy / H. V. Katolyk, J. Binnebesel // Psychology and personality. 2015. No. 2 (8), part 2. P. 208-222.

Palliative and hospice care: extra-medical multidimensional aspects / under the scientific editorship of J. Binnebesel, H. Katolyk. Lviv: Ukrainian Catholic University - Nowa Wies: Wydawnictwo Rolewski, 2018. 411 p. 
Thus, it can be argued that the issue of euthanasia has become a part of modern culture, that is, its values that affect the personal context of the contemporary, and is the subject of analysis at numerous conferences, multimodal congresses, and round tables. This topic is also the subject of controversy in sociology, psychology, philosophy, religion, jurisprudence and medicine. It should be noted that over the past decades, there have been more and more euthanasia advocates among doctors in Europe, Asia and America.

For example, recently published studies conducted in Kazakhstan (Astana) on the attitude of physicians towards euthanasia revealed interesting results (the sample included doctors, teachers of the Medical Academy, employees of the Ministry of Health, physician's assistants and nurses): almost half of the healthcare workers support euthanasia ${ }^{12}$.

The issue of respect for human dignity was debated contentiously at the international multimodal conference "Is there life in a coma?" held in Torun (Poland) in 2013, and they stated that it was always associated with recognizing one's own will to make choice in accordance with spiritual values. They also discussed the issue of whether it is ethical to allow any medical manoeuvres that knowingly lead to the death of the patient. It was noted that people's trust in doctors is based on the fact that idea behind medicine is to heal, so its capabilities should not be used to hasten death. The prohibition to "kill" can be interpreted as an attempt to protect a doctor from committing a crime, and it is of both practical and symbolic significance - to preserve the social status of medicine as well as the patient's life. Examples of patients returning to life after being in a coma for more than 10 years were give $^{13}$. The existence of the issue that euthanasia sometimes takes the form of subjective mercy was also discussed, but from an objective point of view such manipulation can harm the medical profession in particular and the society in general. In the context of the existential approach, let us turn to the values of V. Frankl who, having gone through the horrors of concentration camps and possessing vast scientific and clinical experience working with suicidal and post-traumatic patients, stated that it was not for the doctor to

Phillips P., "Physician-assisted suicide, euthanasia and palliative sedation: attitudes and knowledge of medical students", GMS Journal for Medical Education, 2016. 42 p.

${ }^{12}$ McLennan M., "The revised death fantasy scale: a measure of reaction to anticipatory contemplation of personal death", The Australian Counseling Psychology, 1994. 232 p.

petition.kmu.gov.ua > kmu > Petition > View

irbis-nbuv.gov.ua > cgi-bin > irbis_nbuv > cgiirbis_64 > jnn_2014_1

${ }^{13}$ Andrusiv S.V. Criminal Law of Ukraine: Special Part. Textbook; Ed. by P.S. Matyshevskyi et al. K. : Yurinkom Inter, 1999. 45 p.

Baergen R., "Ethics at the end of life", Idaho state university, 2001. P. 1-38, 42-46.

Fenigsen R., M.D., Ph.D., "Other people's lives: reflections on medicine ethics and euthanasia", New Jersey, 2011. 
determine whether a person's life had any value. The doctor is burdened with the only duty - to help in all circumstances and creatively use any opportunities for this. K. Morris, in turn, argues: if the patients and their relatives were not convinced that the doctor was responsible and diligent in his/her duties, they would never trust him/her. Otherwise, the patient would not have confidence who the doctor was for him - the saviour or the executioner ${ }^{14}$.

Based on the theoretical analysis of scientific research on the sociohistorical aspect of the phenomenon of euthanasia and the value-based attitude of physicians to this phenomenon, as well as analysing the dynamics of social changes in terms of the social value of euthanasia and in accordance with the subject of the study, we have singled out the psychological components of this phenomenon, namely: attitude to euthanasia, values, accentuations, empathy, perception of euthanasia, implicit experience and explicit experience, which involve the formation of new psychological structures in the context of acquired and transgenerative experiences. Based on this vision, we have built a hypothetical model of attitudes towards euthanasia, which is as follows:

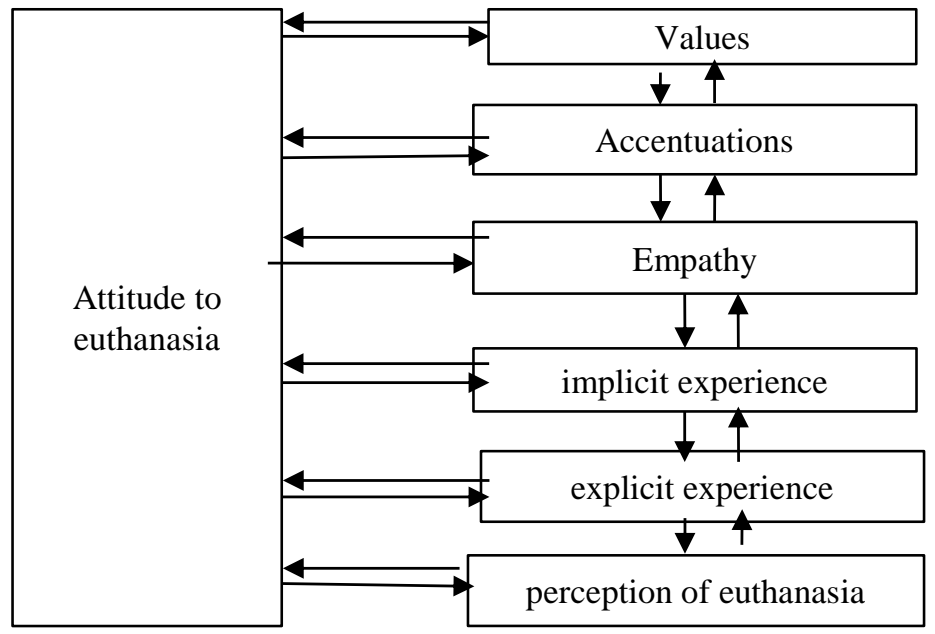

Fig. 1. A hypothetical model of attitude to euthanasia

${ }^{14}$ Study Guide: An Introduction to Bioethics. / Ed. by B.G. Yudin, P.D. Tishchenko. M. : Progress-Tradition, 1998. 190 p.

McLennan M., "The revised death fantasy scale: a measure of reaction to anticipatory contemplation of personal death", The Australian Counseling Psychology, 1994. 232 p.

Morris K.N., "Trends in intake and outcome data for animal shelters in Colorado", Journal of the American Veterinary Medical Association, February, 2009. P. 98-153. 


\begin{tabular}{|c|c|c|c|c|}
\hline & Positive & Negative & Indifferent & Your option \\
\hline 1 & + & & & \\
\hline 2 & & + & & \\
\hline 3 & + & & & \\
\hline 4 & & & & $50 / 50$ \\
\hline 5 & & + & & \\
\hline 6 & + & & & \\
\hline 7 & & + & & \\
\hline 8 & + & & & \\
\hline 9 & + & & & \\
\hline 10 & + & & & \\
\hline 11 & + & & & \\
\hline 12 & + & & & \\
\hline 13 & & & & it is debatable \\
\hline 14 & + & & & \\
\hline 15 & + & & & \\
\hline 16 & + & & & \\
\hline 17 & + & & & \\
\hline 18 & + & & & \\
\hline 19 & & + & & \\
\hline 20 & & & & $\begin{array}{c}\text { it allows for the possibility in certain } \\
\text { cases }\end{array}$ \\
\hline 21 & + & & & \\
\hline 22 & & + & & \\
\hline 23 & + & & & \\
\hline 24 & & + & & \\
\hline 25 & & & & it depends on the case \\
\hline 26 & & & & it is debatable \\
\hline 27 & + & & & \\
\hline 28 & + & & & \\
\hline 29 & + & & & \\
\hline 30 & + & & & \\
\hline 31 & & + & & \\
\hline 32 & & & & $\begin{array}{l}\text { it's not outside the realm of } \\
\text { possibility }\end{array}$ \\
\hline 33 & + & & & \\
\hline 34 & + & & & \\
\hline 35 & + & & & \\
\hline 36 & + & & & \\
\hline 37 & + & & & \\
\hline 38 & & & & as a compromise \\
\hline 39 & + & & & \\
\hline 40 & & + & & \\
\hline 41 & & + & & \\
\hline 42 & & + & & \\
\hline 43 & + & & & \\
\hline 44 & + & & & \\
\hline 45 & + & & & \\
\hline 46 & + & & & \\
\hline
\end{tabular}

Fig. 2.1. The distribution of subjects according to their attitudes towards euthanasia 
This model reflects the interdependence of attitude to euthanasia and ideas (perceptions) about it, values shared by the individual, his/her accentuations, level of empathy, implicit and explicit experiences. This allowed us to select adequate methodological tools for carrying out further empirical research of this phenomenon in a group of subjects, which consisted of senior medical students of the medical university.

\section{Empirical research of the attitudes of medical students towards euthanasia}

The study was conducted by Halyna Katolyk and Mariia Levkut. It involved 46 4-6-year students at the Medical University at the Department of General Medicine, of which 33 were female and 13 were male students. The age of the subjects was 20-22 years.

Below the table is PRESENTED (Fig. 2.1), which demonstrates the attitudes to euthanasia. The respondents were offered the following possible answers: a) positively b) negatively, c) indifferently; and also, the subjects could provide their own answer.

Based on the obtained data, a graphical presentation of the distribution of the subjects according to their attitudes towards euthanasia was constructed, which is shown in Fig. 2.2.

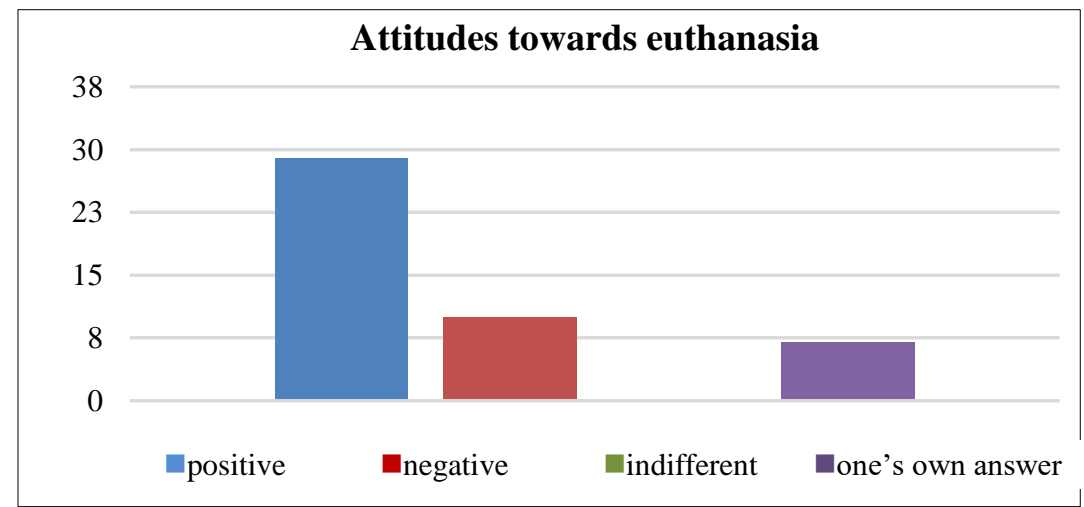

Fig. 2.2. Graphical presentation of attitudes towards euthanasia among medical students

Among the subjects, 29 students have a positive attitude to euthanasia, a negative attitude is formed in 10 students, and 7 students gave their own answers, such as: debatable; compromise; depends on the case; 50/50; allows for the possibility of euthanasia in specific cases. 
We also built a table where we reflected the types of personality accentuations of the subjects, according to the Leonhard-Schmishek method (Fig. 2.3):

\begin{tabular}{|l|c|}
\hline \multicolumn{1}{|c|}{ Types } & Number of students \\
\hline Demonstrative & 5 \\
\hline Pedantic & 5 \\
\hline Stuck & 8 \\
\hline Excitable & 3 \\
\hline Hyperthymic & 4 \\
\hline Dysthymic & 2 \\
\hline Anxious and fearful & 9 \\
\hline Cyclothymic & 3 \\
\hline Affective and exalted & 4 \\
\hline Emotive & 3 \\
\hline
\end{tabular}

Fig. 2.3. The distribution of subjects by types of personality accentuations (Leonhard-Schmishek questionnaire)

Based on the data obtained from the table related to the distribution of the subjects by types of personality accentuations, a graphical presentation of the distribution of subjects by personality accentuations was constructed, as shown in Fig. 2.3.

\section{Personality accentuations, according to Leonhard-Schmishek's questionnaire}

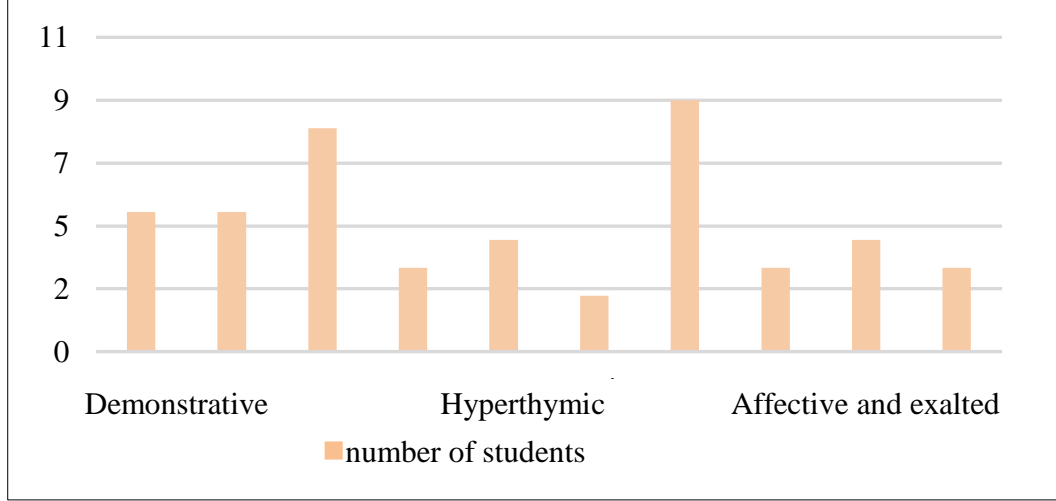

Fig. 2.4. The distribution of subjects according to personality accentuations (Leonhard-Schmishek questionnaire) 
According to the data obtained after the distribution of subjects according to personality accentuations, it was found that the prevailing accentuations among medical students were stuck and anxious (fearful) types. Based on these results, it can be assumed that the vast majority of medical students have a certain kind of fears; they are also easily exposed to vivid affective adventures and cannot get rid of them for a long time.

The table presented in Fig. 2.5 demonstrates the level of empathy in medical students, according to the methodology developed by A. Mehrabian and N. Epstein.

\begin{tabular}{|c|c|c|}
$\begin{array}{c}\text { High level } \\
\text { of empathy }\end{array}$ & $\begin{array}{c}\text { Medium level } \\
\text { of empathy }\end{array}$ & $\begin{array}{c}\text { Low level } \\
\text { of empathy }\end{array}$ \\
\hline
\end{tabular}

16

13

17

Fig. 2.5. Levels of empathy in medical students, according to the questionnaire by A. Mehrabian and N. Epstein.

Among 46 medical students, 17 students have the lowest level of empathy. The diagram below (presented in Fig. 2.6) shows the levels of empathy in medical students.

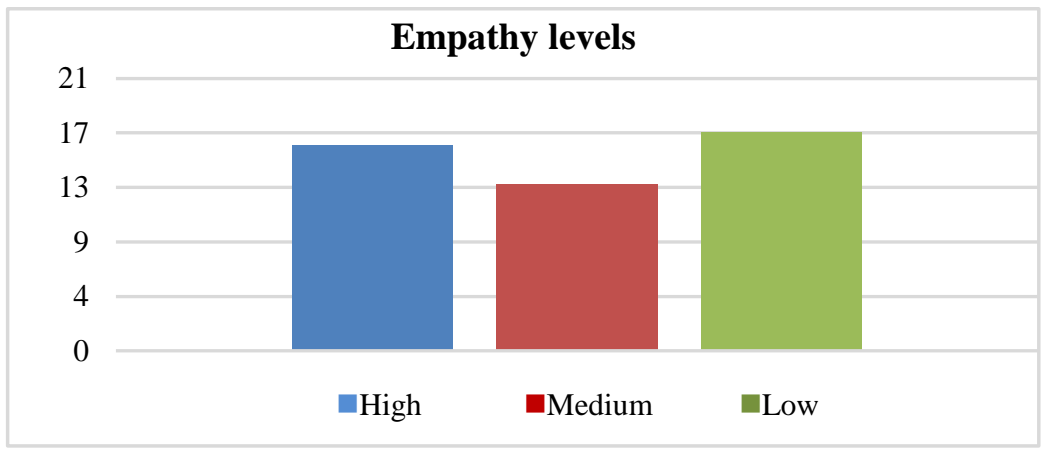

\section{Fig.2.6. Levels of empathic ability (questionnaire by A. Mehrabian and N. Epstein)}

Among the subjects (46 students), 16 of them have a high level of empathy, 13 - medium, and 17 - low level of empathy. It can be assumed that the low level of empathy in the majority of the respondents could be caused by their implicit and explicit experiences and be formed by the combination of their personal experience and training at the medical university. 


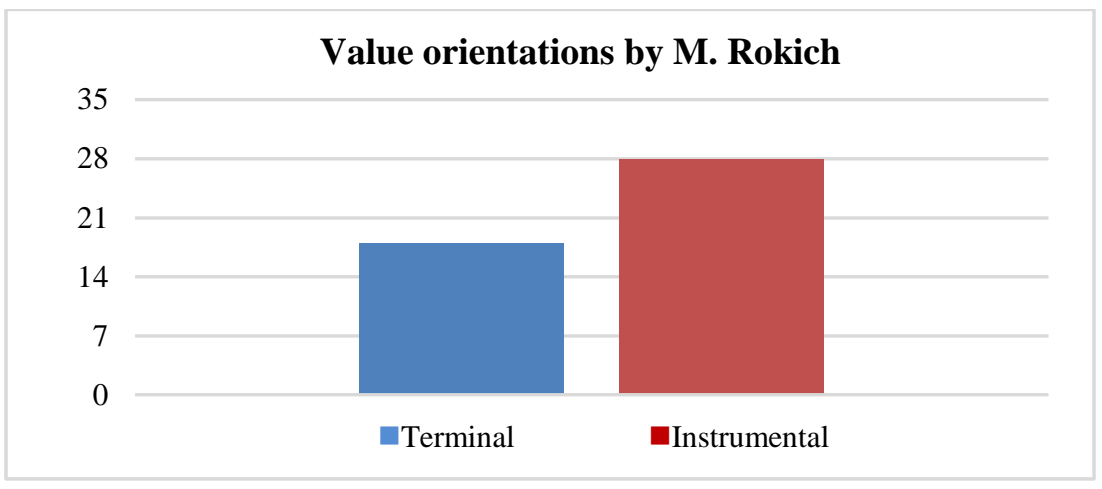

Fig. 2.7. Graphically presented distribution of the subjects by their value orientations (questionnaire by M. Rokich)

Among the students-respondents, 18 have terminal values (beliefs that some ultimate goal of individual existence is worth striving for) and 28 students have instrumental values (beliefs that any kind of action or personality trait is preferred in an individual situation).

\section{Comparative analysis}

To conduct a comparative analysis using the Leonhard-Schmishek method of personality accentuations, two prevailing types of personality accentuations in the subjects were identified, which are: a stuck type (46\%) and an anxious type (54\%).

\section{Personality accentuation types}

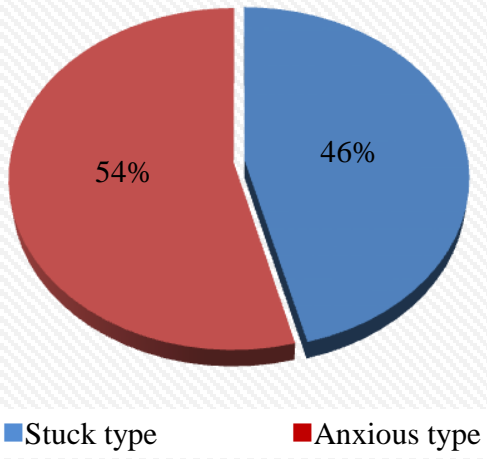

Fig. 2.8. Comparative analysis of types of personality accentuations among medical students using the Leonhard-Schmishek methodology 
To study the empathic ability, we used the questionnaire by A. Mehrabian and N. Epstein. According to this technique, the following results were obtained (Fig. 2.9):

- a group with a high level of empathy (16 individuals, or $34 \%$ of the total number of subjects);

- a group with a medium level of empathy (13 individuals, or $28 \%$ of the total number of subjects);

- a group with a low level of empathy (17 individuals, or $36 \%$ of the total number of subjects).

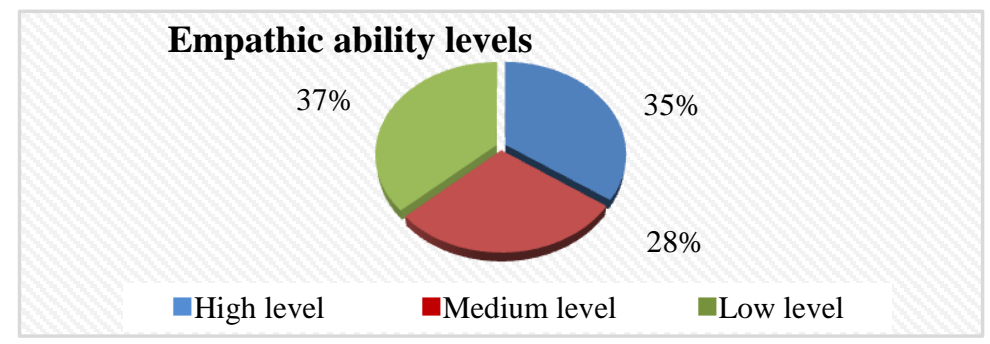

Fig. 2.9. Comparative analysis of empathy levels, according to the technique developed by A. Mehrabian and N. Epstein

For the diagnostics and comparative analysis of value orientations, we used M. Rokich's technique and obtained the following results as presented in Fig. 2.10:

- a group of students with terminal values (the belief that the ultimate goal of individual existence is worth striving for) consists of 18 persons, or 39\%;

- a group of students with instrumental values (the belief that any kind of human action is always preferred in an individual situation) consists of 28 persons, or $61 \%$.

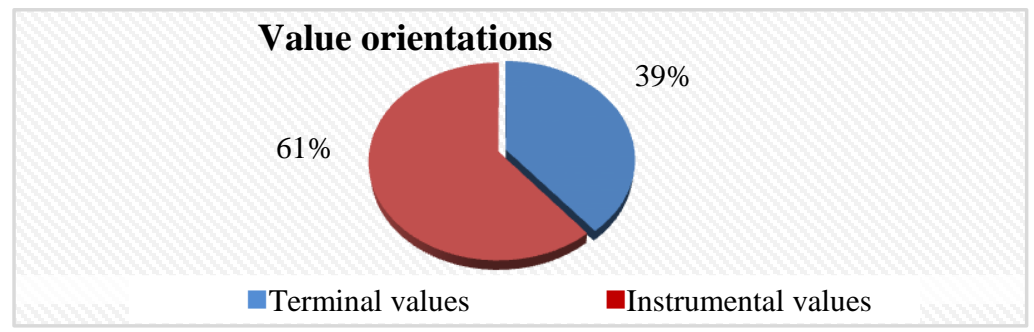

Fig. 2.10. Comparative analysis of terminal and instrumental values, according to the technique by M. Rokich 


\section{Correlation analysis}

Since the aim of our study was to investigate the attitude of medical students to the phenomenon of euthanasia, we conducted a correlation analysis of the data obtained. As far as the data distribution is close to normal, we first calculated the Pearson correlation coefficient. According to the results of the correlation analysis, there is a direct correlation between the attitude to euthanasia and the level of empathy $(r=0.35, p \leq 0.05)$, that is: the lower the level of empathy, the more positive the attitude to euthanasia. Spearman's correlation coefficient data correspond to the preliminary results $(r=0.36$, $\mathrm{p} \leq 0.05)$.

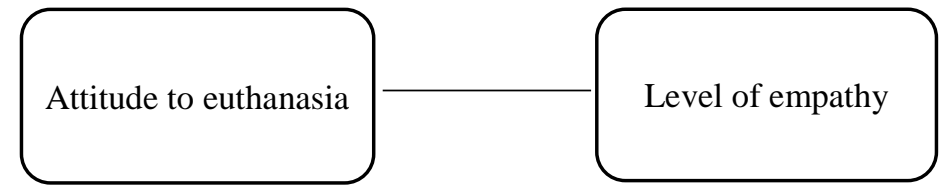

Fig. 2.11. Direct correlation between the attitude to euthanasia and the level of empathy, according to the technique by A. Mehrabian and N. Epstein

A correlation was made between attitudes toward euthanasia and the results of the questionnaire on personality accentuations. Using the Pearson correlation coefficient, we obtained a direct relationship (see Appendix B) between the attitude to euthanasia and personality accentuations of $(r=0.39$, $\mathrm{p} \leq 0.05$ ). Using the Spearman's correlation coefficient (see Appendix B), we obtained similar results $(r=0.36, \mathrm{p} \leq 0.05)$.

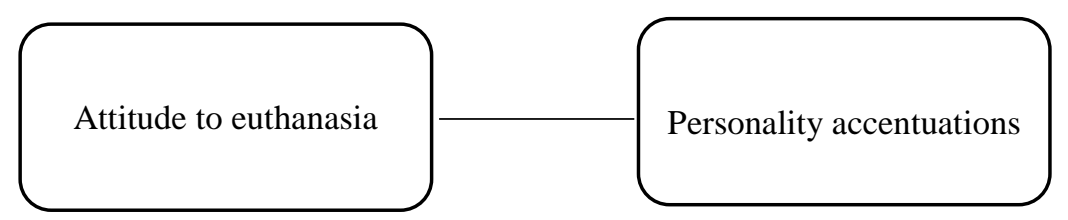

Fig. 2.12. Direct correlation between attitudes to euthanasia and personality accentuations, according to the Leonhard-Schmishek questionnaire

We also obtained a direct relationship between instrumental and terminal values and attitudes toward euthanasia (see Appendix B) $(r=0.41, p \leq 0.05)$ using the Pearson's correlation coefficient. Similar results $(r=0.44, p \leq 0.05)$ were obtained when using the Spearman's correlation coefficient (see Appendix B). 


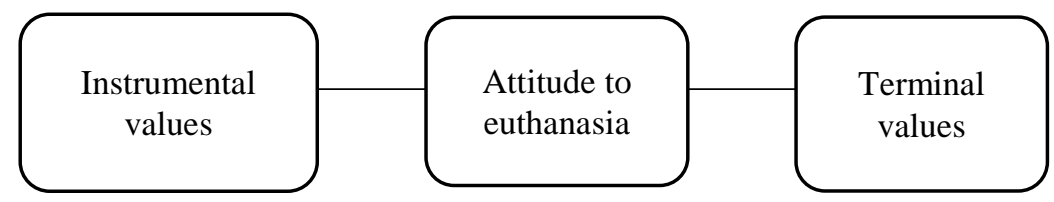

\section{Fig. 2.13. Direct correlation between the attitude to euthanasia and instrumental and terminal values, according to M. Rokich's technique}

It can be assumed that for medical students who see the suffering of people every day, empathy accompanies their desire to help the patient avoid suffering. In many cases, in their opinion, this can only be done by depriving people of their lives, since other possibilities are exhausted and are not effective.

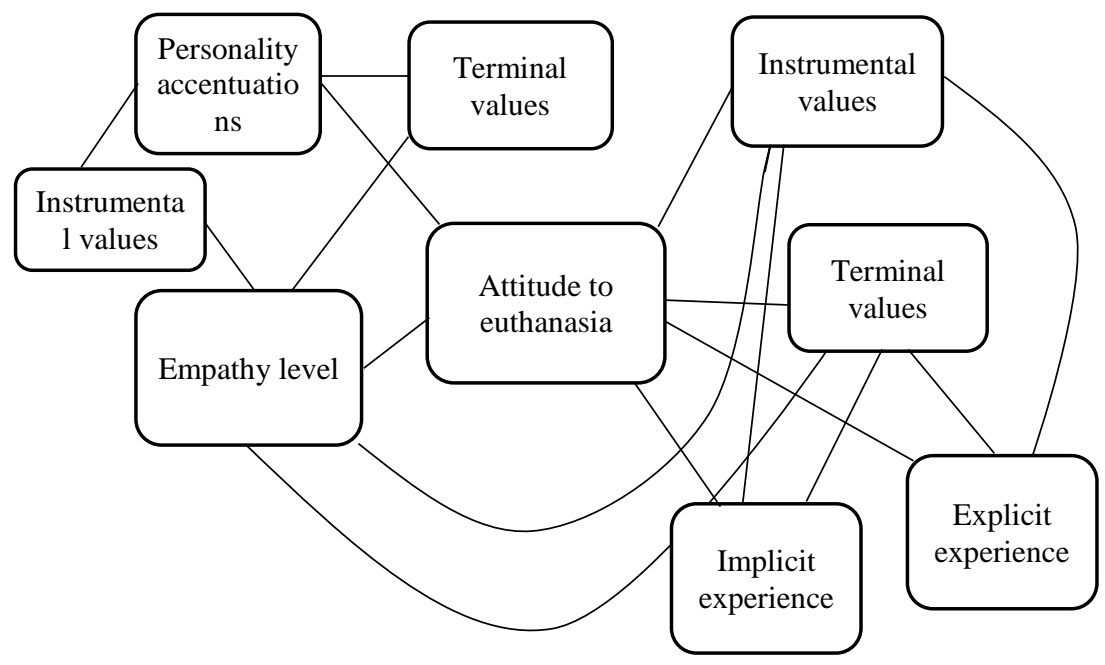

Fig. 2.14. General pleiade of direct relationships between the phenomena

In the general pleiade of possible direct relationships, we have tracked the correlation between the following phenomena: attitudes toward euthanasia correlate with personality accentuations $(r=0.39, p \leq 0.05)$, with the level of empathy $(r=0.35, p \leq 0.05)$, with terminal and instrumental values $(r=0.41$, $\mathrm{p} \leq 0.05$ ), and are connected with implicit and explicit experiences (according to a qualitative analysis). Personal accentuations correlate with instrumental and terminal values $(r=0.29, p \leq 0.05)$ as well as with the attitude to euthanasia. Terminal and instrumental values, in turn, correlate with the level 
of empathy $(\mathrm{r}=0.31, \mathrm{p} \leq 0.05)$ and have a correlation with implicit and explicit experiences (according to the results of a qualitative analysis).

\section{Qualitative analysis}

To study latent, existential meanings the students have regarding the phenomenon of euthanasia, we applied the projective technique "Drawingsymbol of the representation of euthanasia". This technique looks as follows: after the primary immersion of the subjects in the state of encountering this manipulation and the meanings of euthanasia, students visualized them in a symbol followed by depicting it in a picture on a piece of paper. In the study group, 9 subgroups were identified according to the themes of the drawings, which were differentiated by their plotlines:

- Group 1. The plot is "Interaction". During the study, the subjects in their interaction raised a whole gamut of emotions associated with their own explicit and implicit experiences, and recreated certain personal experiences.

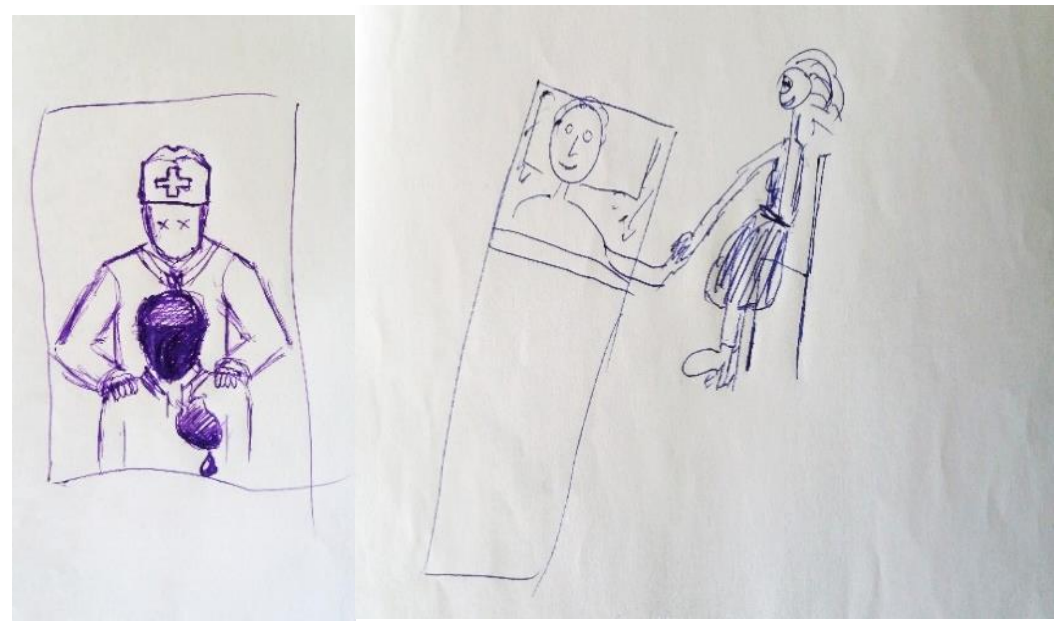

Fig. 2.15. An example of a symbolic drawing of the phenomenon of euthanasia by the subjects from the "Interaction" group.

- Group 2. The plot is the "Syringe as a tool". Through this object, a change in the state occurs. Own experiences and feelings associated with medical manipulations that students have gone through (we assume that these may be childhood fears associated with a painful and traumatic experience when dealing with medical manipulations). 


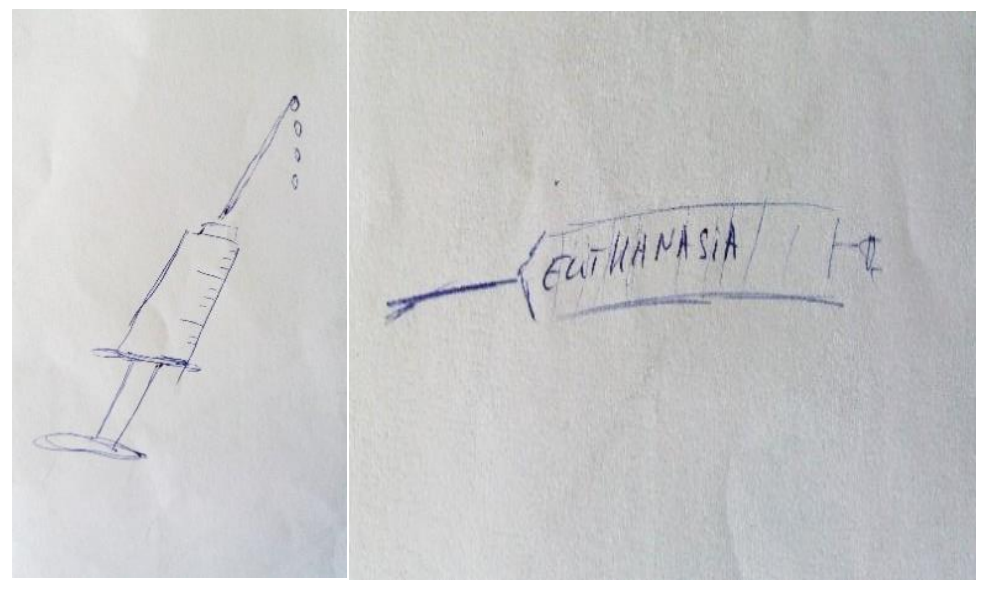

Fig. 2.16. An example of a symbolic drawing of the phenomenon of euthanasia by the subjects from the group "Syringe as a tool"

- Group 3. The plot is the "Crosses". This group includes drawings with archetypal symbols. Concentration on the crosses indicates a specific collective transition from one state to another - through suffering to purification and happiness.

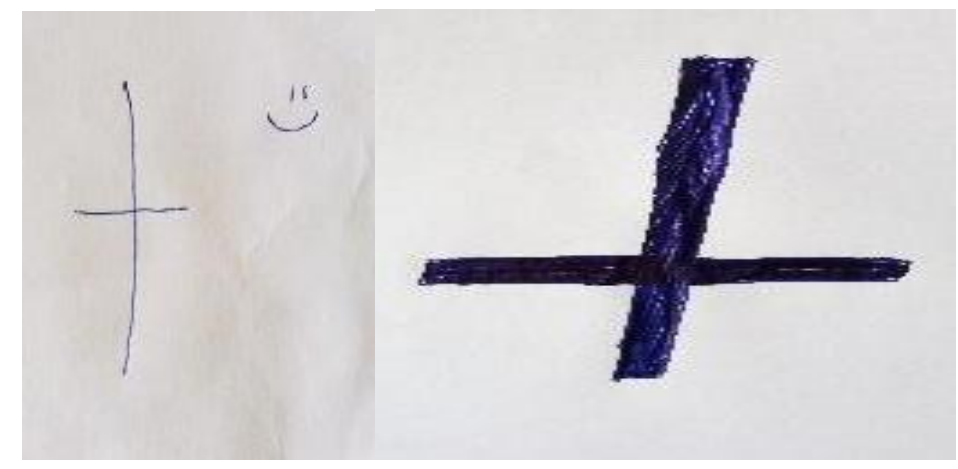

Fig. 2.17. An example of a symbolic drawing of the phenomenon of euthanasia by the subjects from the group "Crosses"

- Group 4. The plot is the "Emotion of sorrow". The person's face is in suffering, which may indicate rueful feelings. The absence of people and relationships in the picture leads us to the idea of infant suffering and separation from the body. 


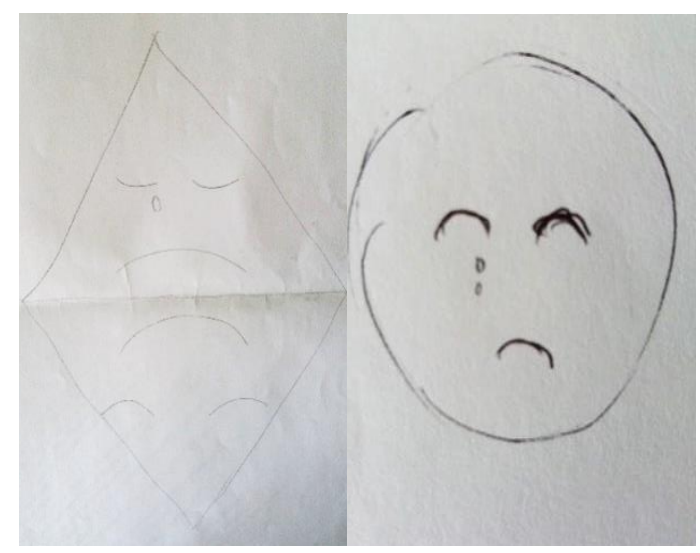

Fig. 2.18. An example of a symbolic drawing of the phenomenon of euthanasia by the subjects from the group "Emotion of sorrow"

- Group 5. The plot is the "Symbolism". The archetypal experience manifests itself in the subjects, and it is embodied in archetypal symbolism (a fading candle, a symbol of death, a symbol of a serpent with a bowl, a key, the Sun, and the Moon). We can assume that comprehension of this situation leads the subjects to encounter universal human basic archetypal symbols and experiences.

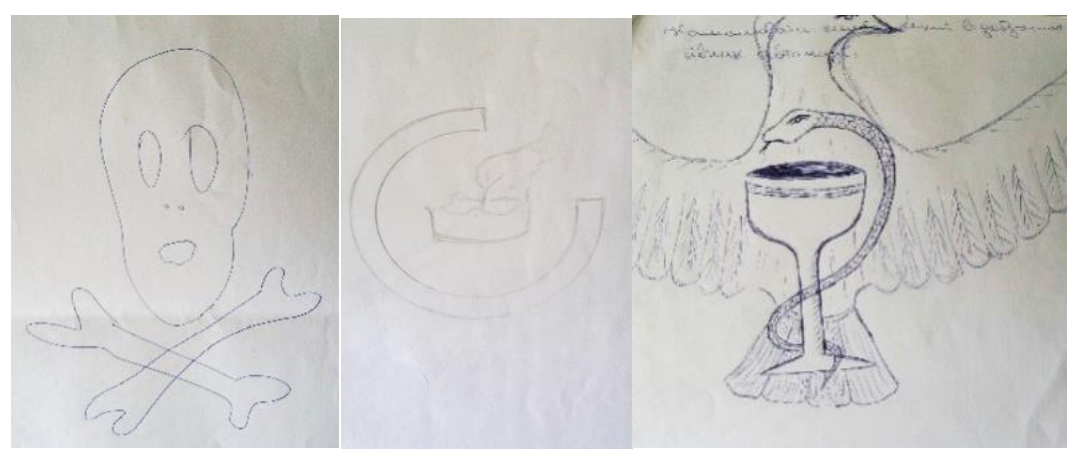

Fig. 2.19. An example of a symbolic drawing of the phenomenon of euthanasia by the subjects from the group "Symbolism"

- Group 6. The plot is the "Natural Phenomena". The subjects may have complex life questions of an existential nature in space and time. 


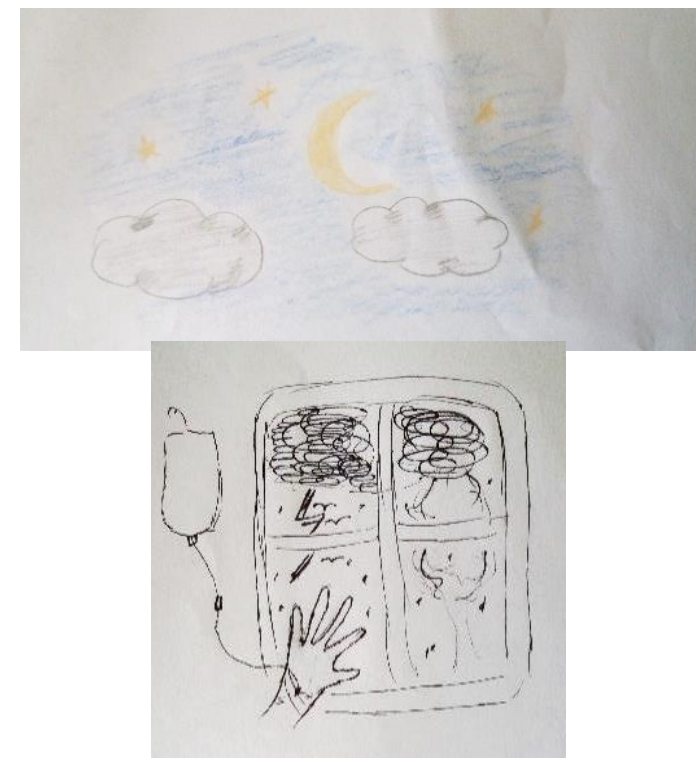

Fig. 2.20. An example of a symbolic drawing of the phenomenon of euthanasia by the subjects from the group "Natural Phenomena"

- Group 7. The plot is the "Interrupted baseline". Such an image conveys the transition of the heart rate in the baseline and may indicate professional experience (dissociated perception of euthanasia).

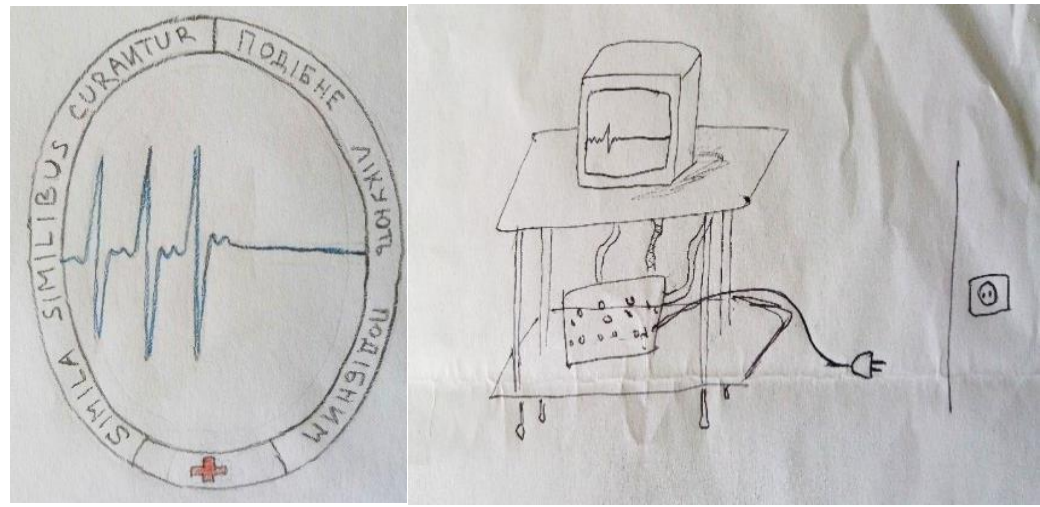

Fig. 2.21. An example of a symbolic drawing of the phenomenon of euthanasia by the subjects from the group "Interrupted baseline" 
- Group 8. The plot is the "Car on the road". It may indicate euthanasia as a certain path that a suffering person must go. A car can be a symbolic transition from one state of a person to another; can relieve the patient from undesirable torment; to transfer him/her to a "better life".

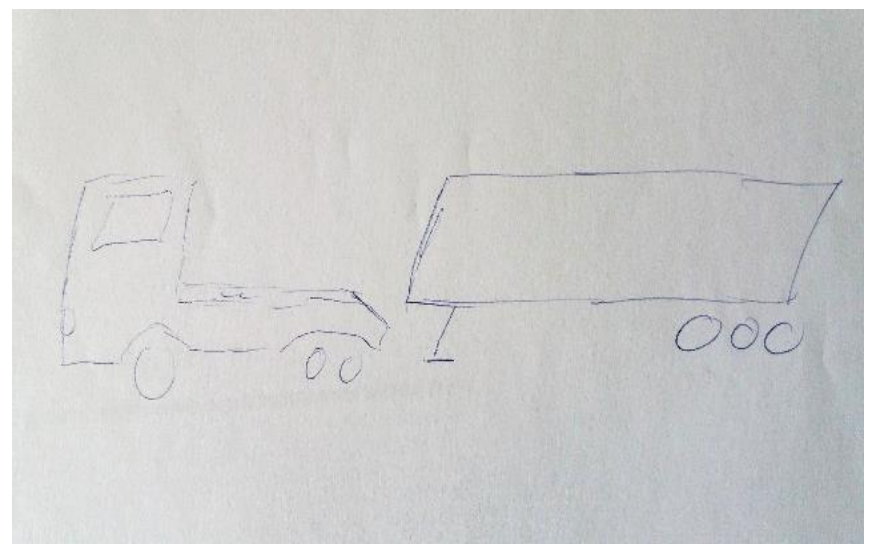

Fig. 2.22. An example of a symbolic drawing of the phenomenon of euthanasia by the subjects from the group "Car on the Road"

- Group 9. The plot is the "Void". An empty piece of paper with the caption "everything is drawn here". Refusal or unwillingness to draw an image may indicate, to some extent, an escape from reality or a hidden sense, a lack of emotions, a depressive state and the like.

Зобразіть, будь ласка, малюнок-символ, який, на Вашу думку, відображае явище евтаназіт.

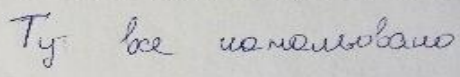

Fig. 2.23. An example of a symbolic drawing of the phenomenon of euthanasia by the subjects from the group "Void" 


\section{SUMMARY}

In the final processing of the results of the empirical study, the following trends have been identified:

- there is invariance in ideas and attitudes towards euthanasia among medical students, namely: 29 students have a positive attitude to euthanasia, 10 students have a formed negative attitude, and 7 students gave their own version presented in the following answers: debatable; compromise; depends on the case; 50/50; allows for the possibility of euthanasia in specific cases.

- According to the distribution of medical students under study based on their personality accentuations, we obtained the following results: 5 students are of demonstrative and pedantic types, 8 students - stuck type, 3 students excitable, emotive and cyclothymic types, 4 students - hyperthymic and affective-exalted types, and 9 students are of anxious type.

- Among 46 students: 16 have a high level of empathy, 13 - medium and 17 - low level of empathy. Using correlation analysis, we observe a direct correlation between the attitude to euthanasia and the level of empathy, which negates our hypothesis that, in the presence of a high level of empathy, there is a negative attitude towards euthanasia.

- There are differences in terminal and instrumental values among medical students: there are 18 students who share terminal values (the belief that the ultimate goal of individual existence is worth striving for), and 28 students with instrumental values (belief that any kind of action or personality trait is preferred in an individual situation).

Based on qualitative and correlation analyses, we can conclude that there are different projections of one's own implicit and explicit experiences related on the phenomenon of euthanasia. Implicit experience influences the formation of attitudes toward euthanasia through early unconscious experienced situations or transgenerational experiences that are in a latent state. With the help of external triggers, in particular visualization and identification with the situation, the existence of the attitude towards euthanasia manifests itself in the context of the interaction of conscious and unconscious life values.

When analysing the results obtained, it can be summarized that the vast majority of 4-6-year medical students majoring in General Medicine have a positive attitude towards euthanasia. These studies require continuation and greater detail, which will be the subject of further research.

\section{REFERENCES}

1. Андрусів С.В. Кримінальне право України: Особлива частина. Підручник; За ред. П.С. Матишевського та ін. К.: Юрінком Інтер, 1999. $45 \mathrm{c.}$ 
2. Арнольд Дж. Тойнби Роль личности в истории / А. Дж. Тойнби. Изд-во: “Харвест”, “Астрель”, 2012 г. 114 с.

3. Байер К., Шейнберг Л. Здоровый образ жизни / К. Байер, Л. Шейнберг ; [пер. с англ. М. Д. Гроздовой [и др.]. М. : Мир, 1997. $368 \mathrm{c}$.

4. Біннебезель Й., Католик Г. Сприйняття страху смерті в контексті замісної реляційної терапії та танатопедагогіки / Г.В. Католик, Й. Біннебезель // Психологія і особистість. 2015. № 2 (8), ч. 2. С. 208-222.

5. Большой толковый социологический словарь. В 2-х т. Т. 2. М: Вече; АСТ, 2001. 528 с.

6. Выготский Л.С. Психология развития человека / Л.С. Выготский. Изд-во “Смысл” Эксмо, 2005. 109 с.

7. Йосафата с. (Дробик О.) Паліативна допомога як протидія евтаназії / С. Йосафата, (О. Дробик ). Львів, Видавництво “Друкарські куншти", 2011. 181 с.

8. Кириленко Т.С., Мирончак К.В. Особливості переживання страху смерті в різних життєвих ситуаціях: когнітивні, емоційні та поведінкові аспекти. 2010. $82 \mathrm{c.}$

9. Паліативно-хоспісна опіка: позамедичні багатовимірні аспекти / за наук. редакцією Й. Біннебезеля, Г. Католик. Львів : Український Католицький Університет - Nowa Wies : Wydawnictwo Rolewski, 2018. $411 \mathrm{c}$.

10. Примаченко В.Ф. Проблема евтаназії в кримінальному праві України. Вид-во “Право і безпека", 2002. С. 5-11.

11. Парахневич О.С., Портнова А.Г. Специфика переживания страха смерти в возрастно-половом аспекте. Изд-во "Генезис", 2006 г. С. 12-15.

12. Секацкий А.К. Ускользание и обман в поединке со смертью / В кн. Психология умирания и смерти: Хрестоматия / Сост. К.В. Сельченок. Мн.: Харвест, 1998 г. С. 79-82.

13. Сельченок К.В. Анализ внутренних переживаний потребителя / Психология умирания и смерти: Хрестоматия. Изд-во “Харвест”, 1998 г. C. $3-11$.

14. Учебное пособие: Введение в биоэтику. / Ред. Б.Г. Юдин, П.Д. Тищенко. М.: Прогресс-Традиция, 1998. 190 с.

15. Ardelt M., "Effects of Religion and Purpose in Life on Elders' Subjective Well-Being and Attitudes toward Death". Journal of Religious Gerontology, 2002. P. 163-192.

16. Baergen R., "Ethics at the end of life", Idaho state university, 2001. P. 1-38, 42-46.

17. Becker E., "The Denial of Death", New York, 1973. P. 44-62.

18. Campbell C, Fahy T. Suicide and schizophrenia. Psychiatry. 2005. P. 9-47. 
19. Dowbiggin I., "A merciful end: The euthanasia movement in modern America”, New York: Oxford University Press, Inc; 2003. P. 33-63.

20. Fenigsen R., M.D., Ph.D., "Other people's lives: reflections on medicine ethics and euthanasia", New Jersey, 2011. P. 5-45.

21. Phillips P., "Physician-assisted suicide, euthanasia and palliative sedation: attitudes and knowledge of medical students", GMS Journal for Medical Education, 2016. 42 p.

22. Gandhi A.,"Desire for death in cancer patients - an Indian Study", Presented at the International Congress of the International Psycho OncologySociety, Copenhagen, 2004. P. 39-128.

23. Griffin G., "A prospective investigation of suicide ideation, attempts, and use of mental health service among adolescents in substance abuse treatment", 2008. P. 10-59.

24. Hurley K., "Implementing a population health plan in an animal shelter", Blackwell Publishing Professional, Oxord, UK, 2004. P. 48-78.

25. Lock J., An Essay Concerning Human Understanding, "Oxford University Press", 2008. 205 p.

26. Margawani M., "A survey of urban pet ownership", Bali, November, 1995. P. 48-65.

27. Maslow A.H., “A Theory of Human Motivation”, New York, 2004. P. 20-29.

28. McLennan M., "The revised death fantasy scale: a measure of reaction to anticipatory contemplation of personal death", The Australian Counseling Psychology, 1994. 232 p.

29. Morris K.N., "Trends in intake and outcome data for animal shelters in Colorado", Journal of the American Veterinary Medical Association, February, 2009. P. 98-153.

30. O'donnell T.J., "Morals in medicine", The newman press, Westminster, Maryland, 1956. P. 190-193.

31. Piaget J. "The Psychology of Intelligence", Brooklyn, 1947. P. 1-94.

32.petition.kmu.gov.ua > kmu > Petition > View

33.irbis-nbuv.gov.ua > cgi-bin > irbis_nbuv > cgiirbis_64 >jnn_2014_1

\section{Information about the author:} Katolyk H. V.,

Doctor of Psychological Sciences, Professor, Head of the Department of Psychology Lviv State University of Internal Affairs 26, Horodocka str., Lviv, 79007, Ukraine https://orcid.org/0000-0002-2169-0018 